Article

\title{
Tracing the Arc: The Shifting Conceptualizations of Educational "Disadvantage" and "Diversity" at the University of Wisconsin-Madison
}

\author{
Carl Grant * and Alexandra Allweiss \\ Department of Curriculum and Instruction, University of Wisconsin-Madison, Madison, WI 53706-1707, USA; \\ E-Mails: grant@education.wisc.edu (C.G.), aallweiss@wisc.edu (A.A.); Tel.: +1-608-263-6586 (C.G.) \\ * Corresponding author
}

Submitted: 5 March 2014 | In Revised Form: 2 June 2014 | Accepted: 9 July 2014 | Published: 31 July 2014

\begin{abstract}
This article calls attention to the shifting conceptualizations of belonging and inclusion at universities in the U.S. through shifting framings of "educational disadvantage" and "diversity". Historically these concepts have been used in various and shifting ways to think about the "Other" and to determine the lines of inclusion and exclusion to access to higher education spaces. This article uses a leading public university, the University of Wisconsin-Madison, as a historical case study to examine the ways the university has responded to those who have historically been excluded from public higher education spaces and the ways inclusion has been expanded and redefined through struggle. This case study is an invitation to carefully consider the current discourses and policy debates about university "diversity" efforts and the inclusion of "disadvantaged" students. We raise questions about what inclusion means.
\end{abstract}

\section{Keywords}

diversity; disadvantage; higher education; student organizing

\section{Issue}

This article is part of a regular issue of Social Inclusion, edited by Professor Ulf R. Hedetoft (University of Copenhagen, Denmark).

(C) 2014 by the authors; licensee Cogitatio (Lisbon, Portugal). This article is licensed under a Creative Commons Attribution 4.0 International License (CC BY).

\section{Introduction}

Currently, there are discussions on the international and national level about diversity efforts and "disadvantaged" students in higher education. In the United States two recent cases on affirmative action ${ }^{1}$ brought to the U.S. Supreme Court have received substantial media attention (Schuette v. Coalition to Defend Affirmative Action, 2013; Fisher v. University of Texas at Austin, 2013). In Schuette the Court upheld the ban on

\footnotetext{
${ }^{1}$ Affirmative action "refers to positive steps aimed at increasing the inclusion of historically excluded groups" to education (and employment). Affirmative action policies are designed to increase access for historically underrepresented groups through greater outreach and inclusion efforts (American Association for Affirmative Action, 2013).
}

using race as a factor for college admission. In addition, federal and state funding for "diversity initiatives" and scholarships for non-dominant students have been targeted and funds have been decreased (Nelson, 2012). We have also seen attempts to cut funding for, consolidate, or even eliminate ethnic studies in schools and colleges across the country (Arizona, Indiana, Wisconsin, Ohio, Texas) despite the struggles endured to create them (Cammarota \& Romero, 2014; Okihiro, 2010; Indiana Daily Student, 2014; Pereira, 2014).

Given this context it is important to examine the current and historical discourses of both "diversity" (race and ethnicity) and "disadvantage" (socio-economic status) employed by many colleges and universities. ${ }^{2}$

\footnotetext{
2 Because of the race and class histories and policies in the United States, issues of race and socioeconomic status (though
} 
Such an analysis can help uncover the ways higher education institutions include and/or exclude the "Other". Also motivating this analysis is that current neoliberal policies and discourses do not take into account these histories and their complexities; instead neoliberal discourses ignore the structural and historical challenges and barriers to mobility and in doing so contend that personal responsibility and the market are solutions for creating equality and fairness. The increased enrollment of students of color in U.S. colleges and the election and reelection of the country's first Black president have caused many to argue that racism and the exclusion of minoritized students are no longer issues; therefore, measures such as affirmative action and funding for diversity initiatives are no longer necessary (Bonilla-Silva, 2013).

Such a belief was exercised when the University of Wisconsin's admission policies and diversity efforts came under attack in 2011 (University of WisconsinMadison News, 2011). A conservative think tank, the Center for Equal Opportunity (CEO), claimed that the university's admission policies "discriminate against White applicants" (Selman, 2011). CEO argued that the University "unfairly" gave admission preferences to students of color. That said, the Education Optimists (2011) reported that CEO's report was composed using a series of "facts" and statistics that were proven to be incorrect. The report sparked a debate about campus diversity and climate. In addition, the recent call to consolidate ethnic studies departments and programs at UW-Madison has further sparked a number of discussions and meetings between students, faculty and administrators about the importance and histories of these academic spaces.

Across the country students of color have engaged in a variety of efforts to highlight the continued exclusion of their voices and their daily experiences with racism and discrimination on college campuses. While decades ago student protests drew on signs, marches and direct actions or negotiations, student protests of today have also employed social media in addition to these tools. At the University California Los Angeles a group of Black students, the Black Bruins, released a YouTube video condemning the underrepresentation (3.3 percent of undergraduates and graduates) of African Americans on campus (see Stokes, 2013). In addition, students at the UCLA Law School created an online petition with a series of recommendations for improving campus climate (see Change.org petition to Dean Moran, 2014). Students at the University of Michigan used a Twitter campaign (\#BBUM) to document the experiences of Black students on the campus and make a list of

distinct issues) often intersect; thus throughout this paper sometimes we will talk about these issues together, while other times will separate out to show distinction depending on the context and/or policy to which we are referring. seven demands to the university calling for greater diversity efforts and inclusion (Al-Jazeera America, 2014).

Furthermore, social media has been useful in helping student organizations at different campuses connect to one another. The students at UW-Madison have taken part in a movement on social media started by students at Harvard called "I, too, am Harvard." Students posted pictures of themselves with captions that represented their experiences - the UW campaign is called "I, too, am UW-Madison." The "I, too, am Harvard" Tumblr page states that the reason for the campaign is: "Our voices often go unheard on this campus, our experiences are devalued, our presence is questioned-this project is our way of speaking back, of claiming this campus, of standing up to say: We are here. This place is ours."

In order to understand these responses it is important to examine the histories and struggles out of which university diversity initiatives and policies developed, which we do in this paper through a historical case study. Many of the diversity initiatives and policies at the University of Wisconsin-Madison emerged out of student struggle and within the context of larger social movements. Such histories need to be documented and centered within debates about affirmative action, ethnic studies and other campus initiatives to address access, equity and inclusion. Not only is it important to critically explore a history of these struggles, but it is also important to examine the discourses and terms used. Thus, in this paper we provide a historical analysis of the defining terms of university inclusion policies and present an overview of their inception. Whereas space does not allow a complete historical account, we will point to key or transgressive moments in the university's history where notions of inclusion in the campus population are imagined, challenged, and reimagined. To do so, we draw on Anyon's conceptualization of social movements and student organizing to frame the way students at the University of WisconsinMadison (UW-Madison) organized to facilitate greater inclusion and to highlight the work that still needs to be done. While these histories and experiences with "diversity" focus on the University of Wisconsin, they are also deeply connected with those of other universities across the country, especially large public universities (Robinson, Foster, \& Ogilvie, 1969).

Dr. Martin Luther King Jr. said "the arc of the moral universe is long, but it bends towards justice". This paper seeks to explore this arc at UW-Madison. We start by laying out our conceptual and theoretical frameworks and the position from which we, the authors, are writing. We then critically examine the term "disadvantage" through the ways it has been employed historically. This is followed by a discussion of histories of immigration to Wisconsin noting its diversity. Next we continue tracing this arc through a discussion of critical moments where notions of inclusion and exclusion were 
initially established during the founding days of the university and moments later in the university's history where these notions have been challenged and rechallenged. This historical exploration brings us to an analysis of where the university is at this present moment in terms of inclusion and explore if and how exclusion has been challenged. Whereas the setting of this paper is the UW-Madison campus, the goal is in part to reflect on histories of programs supporting non-dominant students to better understand the debates and organizing that are taking place across campuses today.

\section{Social Movements, Organizing and Investments}

We draw on Anyon's (2005) theoretical framework of social movements. Anyon builds on classical approaches to social movement theory that focused on resources and mobilization as well as the work of McAdam, Tarrow and Tilly (2001) who capture the "personal and social processes" (p. 131). Anyon argues that movements are not simply made of "discrete 'waves' of contention," but rather, as was the case for the struggle of civil rights in the U.S., movements are often long and continuous. She states, "while various time periods witness more legally contained than socially transgressive activity, both kinds are present in most decades" (p. 131). We see this in the struggles for inclusion at UW-Madison and student struggles at universities across the country; these have been continuous struggles that may appear to come in 'waves.' Some are open contestations, others are public but with less drama; however, whatever form they take the struggles for inclusion in higher education goes on. This paper in many ways is an example of Anyon's thesis. Significant is that Anyon tells us that organizations are often central to social movements and are not separate from them. Her framework allows us to examine how students organized themselves in the struggles at the university, but were also connected to larger social movements across the country, both in terms of student struggles as well as civil rights. Both Students for a Democratic Society (SDS) ${ }^{3}$ and The Student Nonviolent Coordinating Committee (SNCC) of the 1960s are representative of groups that engaged in campus and national struggles in the U.S.

In conducting our literature review we were reminded of the importance of documenting the histories of these organizations and social movements for others involved in similar struggles as well as future scholars. Here we draw on document analyses and interviews with seven key university administrators who were involved in historical moments discussed in this paper. However, in the writing of this paper, we do not directly reference these interviews in order to maintain the confidentiality of people who are still employed at

${ }^{3}$ We have seen a reemergence of the SDS as of 2006. See http://www.newsds.org the university. In addition, we did not rely only on the interviews; we also examined documents and checked with others key actors to research the story we present here. Each of us came to this research from a different position and history with UW-Madison. Carl is an African American man and a Hoefs-Bascom professor of Curriculum and Instruction. He was a PhD student at UW-Madison and then assumed his current position and was present for a number of the key moments discussed in this paper. Alex is a White Jewish American woman and current PhD student at UW-Madison. She has been present for some of the more recent campus discussions about diversity and inclusion. We have brought each of our positions and experiences together in the writing of this paper through a shared commitment to social justice including a commitment to greater inclusion of all students at UW.

\section{The Birth of the Disadvantaged as a People: $\mathbf{5 0}$ Years in the Making}

Current discussions about access to higher education include two overlapping ideas: (1) student campus diversity as it relates to students from non-dominant groups and (2) the return to 1960s terminology of referring to low-income of students as "disadvantaged." Currently, UW-Madison admission policies, like many U.S. educational institutions, consider and measure diversity along two lines, M/D: "minority" or "multicultural" (according to race and ethnicity) and "disadvantaged" (according to educational opportunities and socioeconomic status). "Disadvantage" has recaptured international attention and the current purpose and meaning is much like it was in the 1960s - with a focus on "social and cultural deficits" (Martinez \& Rury, 2012; Portes, 1996; Valencia, 1997). With such a negative lineage, "disadvantage" as the face of an idea to initiate and bring about current day campus diversity and inclusion demands scrutiny.

This paper grew out of an invitation to participate in a conference in Melbourne, Australia, from the International Alliance of Leading Education Institutes (IALEI). IALEI is an "alliance of 10 leading educational institutions ${ }^{4}$ from around the world." The conference invitation we received read:

Educational disadvantage takes many different forms, but globally is a major barrier to the wellbeing of individuals and communities and the pros-

\footnotetext{
${ }^{4}$ Members of IALEI Include: the University of Melbourne, Australia; University of Sao Paulo, Brazil; University of Toronto, Canada; Beijing Normal University, China; Aarhus University, Denmark; Nanyang Technological University, Singapore; University of Cape Town, South Africa; Seoul National University, South Korea; University of London, UK; and the University of Wisconsin-Madison, USA.
} 
perity of nations. University schools of education are uniquely placed to contribute to the twin tasks of understanding and overcoming educational disadvantage (IALEI, 2012).

We were troubled by the way the word "disadvantage" reflected past deficit notions, but at the same time wanted to engage with it in order to shed light on its problematic framing and implicit othering. This was not an easy task, because we recognized the good intentions of the invitation.

The term "disadvantaged" has been a part of the social and political discourse in the U.S. for years and is popularly used as synonymous with "poor, uninsured, homeless, elderly and frail; and suffering from a range of chronic diseases, or special populations in need, such as Native Americans and low-income veterans..." (Mechanic \& Tanner, 2007). To those descriptors and others one can add deficit-oriented terms related to conflations of cultural and racial identity and poverty that have historically been used in education literature and the media to highlight "disadvantage": culturally disadvantaged, culturally deprived, welfare queens, homeless, hobos and bums.

In the 1960s, "disadvantage" became a household word in the U.S. used in reference to groups of people rather than socio-economic conditions or structures (see Crow, 1966). This word took on meaning during the time of a major social conscious awareness brought on by President Johnson's address on poverty. In the 1964, Johnson spoke out forcefully and caringly for "the disadvantaged". He made poverty an official national and political concern and put in motion a series of legislative actions in health, education and welfare. Responding to the push from Civil Rights activists Johnson created programs such as Head Start, food stamps, work-study, Medicare and Medicaid that still exist today (Siegel, 2004). The "War on Poverty" legislation (as it was called) had a major impact in most places and on most people throughout the country. Not only did it help a number of people get jobs, but the War on Poverty also had an impact on education with two significant pieces of legislation: Head Start and Project Follow Through. Head Start is a preschool program designed to bring education, health and social services to low income children in order to prepare them for their kindergarten experience. And Project Follow Through is designed to extend the services started with Head Start and to plant poor students firmly on the road toward a successful K-12 experience with college as a future expectation (Tyack \& Cuban, 1995).

Besides academic assistance, students' had experiences attending professional plays, visiting museums, art galleries, concerts and zoos. Artists and storytellers from different ethnic and racial backgrounds visited schools and engaged students in discussions about places and opportunities outside of their own milieu.
However, fundamental to many of these "opportunities" was a White middle-class perspective; and absent from many of these "opportunities" was a perspective that acknowledged and showed appreciation for the histories and cultures of the students. The understandings of disadvantage in the U.S. proceeded from a deficit perspective that viewed the targeted students as socially and culturally deprived or not having the "right" culture to succeed (Riessman, 1962; Deutsch, 1967; Ornstein, 1970). These notions led to a blaming of the individual for failing to succeed and a framing of "disadvantaged" students within a deficit framework (Valencia, 1997). While the term and idea of "disadvantage" can be expanded to account for systemic and structural inequities, the way disadvantage is addressed in practice generally continues to focus on the individual and not the social structures that gave rise to it. Within this discourse and framing the label of "disadvantage" is potentially harmful as there is an implicit power for it to identify, explain and predict the futures of those labeled as members of "disadvantaged" groups. There is power in naming (Fairclough, 1989). As we continue through this paper, it is important to keep the histories of the terms used in mind, because they are generally employed by universities absent of their histories. Words matter, they carry meaning and situate action (Ryan, 2014).

\section{Weaving the Social Fabric}

To understand the current situation and how otherness has been constructed at UW-Madison through the "M/D" categories, we looked at the social history of the state the university serves. We looked at the "arrival" of different ethnic groups that formed the state to examine how "disadvantage" was constructed in order to complexify the way inclusion at the university continues to be imagined.

A review of documents from the Wisconsin Historical Society on Wisconsin's history gives information on the many racial and ethnic groups that came to Wisconsin and why they came: religious freedom, better life opportunities, and to escape persecution. For years many ethnic and racial groups have called Wisconsin "home." At times the various groups worked together to support one another through challenging times, but at other times there was violence between groups.

Native Americans from the Eastern United States were the first make Wisconsin their home; they include the Dakota Sioux, Ho-chunk (Winnebago), Menominee, Ojibwe, Potawatomi and Fox and Sauk tribes (Schereck, 1956). In 1634, as Frenchman Jean Nicolet was searching for the Northwest Passage, he happened upon land that would one day be Wisconsin. He was discovered by two large Indian tribes living in the area, the Menominee, and the Ho-Chunk (Winnebago). The French set up trading stations in the area. The first records of Black 
people in Wisconsin are those who arrived with the French fur traders in the early 1700 s both as enslaved and free people (Wisconsin Historical Society, n.d.).

The British arrived in the territory in 1763 almost a hundred years after the French and Blacks. They were followed by immigrants from Norway who were escaping poor harvests and famine that occurred during the 1830s (Slesinger \& Parra, 1988). Immigrants from Western Europe, the Netherlands (1840-1850), Belgium (1853), and Luxembourg (1848) arrived between the 1840 s and 1850s (Hale, 1984; Holmes 1990). In the 1840 s, a great number of Irish fleeing the potato famine settled in Wisconsin and a number of immigrants from Wales also made their home there. Immigrants from Eastern Europe (Czechs and Poles) and Southern Europe (Italians and Greeks) also came to Wisconsin during the $19^{\text {th }}$ Century (Holmes, 1990). Around this time, in 1848, the Oneida were pushed off their land and forced to live on a reservation near Green Bay.

Russians came during the first two decades of the $20^{\text {th }}$ Century. The large majority of Latinos arrived in the 1950s - though there have been Spanish-speaking communities in the state since 1910 (Wisconsin Historical Society, 2006). After the Mexican Revolution, a number of people of Mexican heritage began to settle in communities throughout Wisconsin and others came to work for various manufacturing and agricultural contractors. Since then, Latinos have continued to come to Wisconsin for economic and political reasons. Large numbers of Asian immigrants did not settle in Wisconsin until the 1990s, though many Japanese Americans were interned in Wisconsin during World War II. In the 1990s a large number of Hmong people were forced to flee their country after U.S. forces withdrew from Vietnam because they had supported the CIA in fighting the wars in Vietnam and Laos (Haines, 1989).

Many of the people who came to Wisconsin would have been framed as "disadvantaged" according to today's designation-many were trying to escape poverty, displacement and political or religious persecution and came looking for greater opportunities (Long \& Veroff, 2007). Many, if not most, of the immigrants of each and every race and ethnicity saw Wisconsin as "the golden door!" to economic security and a flourishing life. Within this historical framing it is interesting to think about how otherness was constructed and which groups eventually came to be seen as "disadvantaged" and minoritized; and how certain groups, because of their racialized identities, shifted from a position of "disadvantage" and economic struggle to a position of privilege at the expense of groups that came to be seen as the "Other."

As a whole, the state has struggled to meet the needs of its diverse population in and out of schools. Recently, according to NAEP test scores, Wisconsin has the largest achievement gap between White students and students of color in all areas tested: math, science, and reading (National Assessment of Educational Pro- gress, 2013). In addition, a recent report showed Wisconsin, and particularly Dane County where UWMadison is located, as having some of the largest racial disparities in important social and economic measures, such as poverty, incarceration and education rates, in the nation (Race to Equity, 2013). Also Milwaukee, the state's largest city, has been known as one of the most segregated cities in the nation since the 1960s (Wisconsin Historical Society, n.d.). Large numbers of African Americans had moved to Milwaukee during and after World War II, and by the 1960s they accounted for fifteen percent of the population. Most African Americans lived in the "Inner Core," which by the 1960s had become a site of increasing volatility due to limited job opportunities, poverty, and segregation (Wisconsin Historical Society "Turning Points," n.d.). Thus, meeting the needs of the state's diverse population has been and continues to be a challenge. This also influences UW campus life.

UW-Madison has sought to be a force in promoting greater equality across the state. This is highlighted by the Wisconsin Idea, ${ }^{5}$ as stated by President Charles Van Hise in 1904 who declared "I shall never be content until the beneficent influence of the University reaches every home in the state." The Wisconsin Idea continues to guide the actions on the campus in most areas, including slowly but steadily those who have been othered.

\section{Lessons from the Struggles of UW-Madison}

\subsection{0s: The Violence and Exclusion of the Beginning}

UW-Madison's early history and the space the campus occupies complicate the meaning of the "Wisconsin Idea" and raise serious questions about who has been considered to belong (as part of the university). HoChunk and other Native Americans call the Madison area where the university is located Dejope or "Four Lakes". Dejope hosts a number of archeological sites including effigy and burial mounds, "revealing the thousands of years that the Ho-Chunk and other American Indians have called this area home" (University Housing, n.d.). The 1825 Treaty of Peace recognized the land where the University now sits as Ho-Chunk land and promised it "would not be invaded by White settlers" (Greendeer, 2002, p. 3). However, beginning in 1829 the encroachment of immigrant settlers and a series of forced treaties pushed the Ho-Chunk to cede their territories. Thoughts of inclusion or ways to share the land were not part of the thinking of the government or the settlers. Greendeer states, "[A]fter many conflicts, land cessions and removals, the Ho-Chunk

\footnotetext{
${ }^{5}$ Now defined as "the principle that the university should improve people's lives beyond the classroom. It spans UWMadison's teaching, research, outreach and public service" (Wisconsin Idea, n.d.).
} 
were removed from their remaining aboriginal territories in Wisconsin via to the Treaty of 1837." The treaty was intentionally mistranslated to trick the Ho-Chunk into ceding their lands to the U.S. The territory was then brought under U.S. government control giving the government the ability to reallocate the lands and create the University of Wisconsin in 1848 (Greendeer, 2002).

Violence against Native Americans was significant to the creation of UW-Madison and battles and forced removals are a central part of the university's founding history and current landscape. In 1888, the graduating class presented the University with a gift known as the Black Hawk Commemorative Boulder. The Boulder is a testimony to how the U.S. army pushed Native Americans off the land. Also, the statue of President Abraham Lincoln, which sits in the middle of the campus mall, has served as a troubling and unwelcoming figure for Native peoples living in the area because of his participation in the Black Hawk War and presiding over the largest mass execution of Native Americans in U.S. history-the 1862 mass lynching of 38 Dakota men in Mankato, Minnesota (also home to a state university) (Brown, 1971; Meyer, 1993). In addition, the university has not until recently worked to preserve or respect historical monuments and burial mounds of the Native peoples.

It is meaningful that UW-Madison was initially established for White middle class men. This establishment solidified a violent divide between the university and the people whose land it occupied and made the university an exclusionary space. At the same time, UW-Madison early on began to admit some students from historically marginalized communities. The first White women were admitted in 1863 and the first African American was admitted to the law school in 1875; but it was many years before women of color were seen on the campus as students.

What comes to light here is that UW-Madison in its conception was imagined by its founders (White men) as a university for the citizens of the state of Wisconsin (imagined as White men). While at different points in time across the university's history the exclusion of Others has been challenged it has not been fundamentally ruptured. This paper now looks at moments of challenge and change and points out the spaces where a reimagining and full inclusion has failed to take hold.

\subsection{0s: A Push for Change}

When we interviewed former and current administrators responsible for the University's organized response to diversity (and disadvantage) all brought student protests and the Holley Report to our attention; and the Report was always discussed within the context of student protests. Student protests for greater inclusion and equity grew out of the 1960s demonstrations on the Madison campus against the Vietnam War, the Dow Chemical Company, the Army ROTC and the push for Civil Rights. Across the country, areas where students lived were the center of "counterculture" actions (Wells, 2014; Smith, 2012; Williams, 2010).

This was the time of the Black Power and Civil Rights Movements in the U.S. (Ture \& Hamilton, 1992). Black students across the country organized hundreds of protests that ignited struggles and negotiations between students and university administration that slowly led to reforms that transformed college life for all students. Biondi (2012) states,

At stake was the very mission of higher education. Black students demanded that public universities serve their communities; that private universities rethink the mission of elite education; and that black colleges embrace self-determination...Most crucially, black students demanded a role in the definition of scholarly knowledge (p. 27).

On the UW campus, students' organizing focused on the University itself, because officials were dragging their feet and stonewalling against the demands of students of color for a socially inclusive campus.

Ruth Doyle, the first woman elected to the Wisconsin Assembly and a key player in rebuilding the Wisconsin Democratic Party, developed a plan that drew favorable attention among White liberals as a way to deal with and support the changing demographics on the UW-Madison campus. Doyle was an outstanding public servant and a White integrationist who was respected and appreciated by both Blacks and Whites on the UW campus and throughout the Madison community. In 1965, in order to promote Black recruitment, retention and graduation from the university, Doyle spearheaded the development of a Five-Year Program. The program reached out to "disadvantaged" students (mostly students of color) who did not meet the established admission criteria, but demonstrated the potential to be academically successful at UW. Citing the Five Year Program, Gilbert (2011) explains,

In sum, her Five-Year Program had two major objectives: (1) Provide the benefits of higher education to students who, because of difference of academic background, cultural heritage and financial status might never seek or have available the opportunities, which existed at the University of Wisconsin; (2) Add to the student body of the University an additional and important educational dimension through promotions of its own diversification (p. 7).

This was the one of the first racial recruitment efforts at a university. The program helped attract more students of color through an active system of recruitment and support.

The program was lauded as a leading program for di- 
versity and inclusion. However, many students of color on the UW-Madison campus argued that the Five Year Program did not go far enough. Students began to push back against the structure and inherent limitations of the program. They demanded that the university go further to fully include all students within the campus mission and programming. They opposed the assimilationist goals of the program, such as the expectation that students enrolled in the program would take on a teaching role for White students. Also they criticized the program's mandatory five years (when White students could graduate in four). They were angered that they were required to take a lower than average course load, which sent a deficit message that the students in the program could not complete their degree in the same amount of time as other students. In addition to their pushback against the program, they wanted, as Biondi (2012) noted above, to see the scholarly knowledge and historical contributions of people of color articulated in all University courses and activities. Further they wanted the establishment of ethnic studies departments, such as Afro American Studies and the hiring of faculty and staff that would facilitate and lead this reform.

Doyle became a "central symbol of the administration's opposition to the demands Black students were campaigning for" (Gilbert, 2011). In an interview with Donna Hartshorne (1982) for the Wisconsin Historical Society, Doyle explained how she felt when all her hard work and well-meaning efforts came "smash" around her. She told Hartshorne that the pushback by the students was a personal affront, rather than understanding it as a challenge to the university structure. Talking about the leader of the Black Student Alliance, Will(ie) Edwards, Doyle stated, "Willie Edwards...was determined to do me in and he did." She went on to recount,

The uprisings were beginning to occur in various places and here it began when I gave a speech to a luncheon group...about the program in which I said I was opposed and would always oppose anything that would segregate these people, that we didn't need to have a black enclave on this campus, we should have an integrated student body that's what the whole movement was about. And some students took great offense to that. That's when the students were establishing themselves...they wanted a black floor on the dorm, they wanted a black student center...And I must say I was quite firm about my own positions on that. And the students would argue with me...that was in the fall of 1968 and they apparently marched on the Chancellor's office...just a few days later.

Despite her good intentions, Doyle was unwilling to listen to the Black students. Her opposition to the students' demands was rooted in her firm beliefs in integration and that the establishment of a living space for
Blacks, a student center, and/or academic programs would create "Black enclaves." Her belief that she knew what was best for the students, whose interests she claimed to be working for, prevented her from being able to fully listen to their needs and desires. Doyle wanted students of color to fit into the campus rather than seeing that the campus needed to be restructured to reflect a multicultural learning space. Her resistance was not malicious, but rather myopic and reflective of the university's administrative position. While students recognized Doyle's good intentions, they were unwilling to settle and her resistance led the Black students to adopt a position of solidarity and resistance. What is important here is that while we highlight the individual story of Doyle, the issues this story highlights are also systemic and were very much a part of the university discourse and view of underrepresented students.

When they realized that Doyle and other university administrators were unwilling to work with them to meet their needs and give them the spaces they requested, the Black Student Alliance made thirteen "non-negotiable" demands, including firing Doyle. After Chancellor Young also proved unwilling to meet the demands, the students went on strike for weeks. Throughout their activism Black students garnered much support for their cause, including support from many White students on the campus, who joined in during the protests and strikes.

In February of 1969, the National Guard descended on the Madison campus to "control" the protesters. Conservative members of the university administration and state legislators argued that the students were trying to disrupt teaching and bring down the institution (Gilbert, 2011). The call-up of the National Guard had the opposite affect the university administration hoped for; instead of stopping the strike, it helped to garner more support for the Black students' demands, as many students, Black and White, were opposed to the presence of the Guard on campus.

On February 13, 1969 an estimated seven to twelve thousand students came together for a march from the campus to the capital-about a mile (Gilbert, 2011). This mass organizing put pressure on the university administration to make changes. The Chancellor appointed a panel of faculty members and students to review the Special Five Year Program. The review panel's final report demanded that Doyle be fired. The Five-Year Program was brought under new leadership and restructured in an effort to be more sensitive to the students' needs and demands (Gilbert, 2011).

Additionally, the university's curriculum was retooled and the Department of Afro American studies was established in 1970. This Black activism also encouraged other groups on campus to push for the creation of their own departments. In 1968 Native American students began pushing for the university to better serve Wisconsin's Native communities and in 1972 the 
Native American Studies program was established. In 1974, student activists started rallying for a Chicano Studies Department; they were never granted a department, but a Chicano Studies Program was established in 1976. And, in 1988, a group of community and university activists, known as the Asian Coalition, wrote a proposal for the Asian Studies Program, which was established in 1991.

\subsection{0s: Student Struggle and the Creation of Ethnic Studies and Diversity Initiatives}

After a number of racist incidents on the campus, which came to a head with racist caricatures depicted on 1987 invitations for a Frat Party, students went to the administration demanding action. The fraternity was banned from the campus, but students continued to push the administration to make more structural changes. A new chancellor, Donna Shalala, stated that she wanted to be more responsive to the students' demands. That summer a working committee was established to create recommendations for campus improvements in terms of its climate and diversity initiatives. The Steering Committee on Minority Affairs created the Holley Report, named after the committee's chair and head of the Black Student Union, Charles Holley.

The report was an outgrowth of the efforts of students of color and others who pushed for changes that would make the campus responsive academically and socially to all students and faculty. The Holley Report was released on December 1, 1987 and is cited as the seminal document that gave rise to formal efforts to deal with diversity and disadvantage across the university. The Report included several recommendations: the appointment of a Vice Chancellor of Ethnic Minority Affairs to ensure accountability and to be responsible for matters relating to affirmative action; actions to improve the recruitment and retention of minority students including centralized support programs and incentives for faculty and staff to be sensitive and committed to the needs of minority students; increased recruitment, hiring and retention of faculty of color; the creation of an "investigative body" of faculty, staff and students to address the concerns of minority staff members; the creation of a Multicultural Center on campus to house multicultural organizations; the implementation of an ethnic studies course requirement and various Ethnic Studies Programs; the establishment of an orientation program aimed at combating racism and increasing "the level of comfort of students of color" for all members of the University; and outreach to the minority communities in Madison (Holley et al., 1987).

The university administration created the Madison Plan of 1988 (also known as the Design for Diversity) in response to the Committee's recommendations. Taking some of the recommendations of the Holley report, the
Plan sought to increase recruitment and retention of both students and faculty of color, established the Multicultural Center for students, and implemented a 3-credit ethnic studies requirement. While the Madison Plan marked the UW system's first system-wide strategic plan to foster diversity and "establish a culturally enriched academic Environment" (Final Report on Plan 2008, 2009), the Plan was disappointing to many involved with the Holley Report because it was seen to offer an "assimilationist perspective" and had reduced and/or eliminated many of the Committee's recommendations. The initiatives set forth by the Madison Plan have never achieved full inclusion or the depth and sensitivity of the Holley Report's recommendations.

The Plan 2008 was established in 1998 to continue the UW system's commitment to diversity. Both 10year programs (the Madison Plan and the Plan 2008) were "based on the principle that increasing the participation of historically under-served populations would enhance the educational experience of all students, better preparing them to live and work in a multicultural society" (Final Report on Plan 2008, 2009). An evaluation of the overall success of Plan 2008 shows that while the initiative has experienced some success in the increase in recruitment and retention of students, faculty and staff of color these increases have been minimal and many racial and ethnic groups remain underrepresented. Furthermore, the establishment of an inclusive and diverse academic environment has not been achieved (Final Report on Plan $2008,2009)$. Currently, the University is in the process of creating a new diversity plan to address these shortcomings.

\section{The Current Focus}

UW-Madison was not the only place where struggles for greater inclusion and representation were taking place. Across the country students of color have demanded spaces in their institutions and have insisted that their voices and perspectives be heard and represented. They have argued for curricular changes, courses that represented their histories and perspectives, professors from non-dominant backgrounds, and departments that address their history and culture (see Stanford Historical Society, 2011). Many student struggles gained traction and continue to today. Current examples include the University of Michigan's Black Student Union demands for the university administration to create a more inclusive campus climate, (Al Jazeera America, 2014), Dartmouth's Afro-American Society's effort to "end oppression on campus" (Torres, 2014), and the University of California- Santa Barbara's Black Student Union's demands to change the "hostile racial climate throughout the UC system" (Torres, 2014). Also student are pushing for tuition equity for undocument- 
ed students at state universities across the country (Lucha y Resiste, 2013). Equity has yet to be achieved and struggles continue at universities across the country.

When UW alumni look across the years, they will see that there has been an increase in the number of "minoritized" students (undergraduate, graduate and professional) on the campus. However, enrollment numbers for students of color remain low when compared to other AAU (Association of American Universities, which includes 61 leading research universities in the U.S. and Canada) and public universities. The 2011 Diversity Forum cited an increase to $9.9 \%$ for "Targeted Minority" or African American, Native American, Hispanic/Latino/a, and Southeast Asian (Cambodians, Laotians, Vietnamese, and Hmong) student enrollment (definition from Plan 2008, 1998). ${ }^{6}$ Not only are student enrollment rates low, but graduation and retention rates for $M / D$ targeted students remain well below all-campus averages. To combat these trends, there are a number of programs at UW-Madison that aim to increase access and success for underrepresented populations: precollege preparation, academic support services, and access to scholarships and financial supports.

As of the Fall 2011, the School of Education (SOE) has the largest percentage (16\%) of "targeted minority" graduate students compared to other graduate and professional schools on campus. SOE has $10 \%$ of undergraduate students who are considered "targeted minorities" (Diversity Forum, 2011). Women, who were once considered an underrepresented group, now make up more than half of the undergraduate and graduate student population for the entire university. However, subject areas are still highly gendered as to this day women are considered underrepresented in areas such as Engineering and Mathematics.

The hiring and retention of faculty of color is also a particular concern of the University. As of 2010 there were 2,177 total faculty members and $17.6 \%$ (384) of faculty were "racial/ethnic minorities." This represents an $8 \%$ increase in minoritized faculty since 1996 (Diversity Forum, 2011). However, the increase has not been a consistent trend. Some years it has risen and other years it has fallen. Another concern is that the tenure rates of minoritized faculty remain below their White colleagues. There is a $70 \%$ tenure rate for White faculty and a $65 \%$ tenure rate for "minority" faculty (Diversity Forum, 2011). As former Vice-provost, Damon Williams, stated in a personal interview this is not a startling difference, but when considering the fact that minoritized faculty are underrepresented in the University, these low tenure rates can be decimating for the number of faculty of color on the campus.

Also Williams (2013) argues it is necessary to go beyond access and examine the campus climate and

${ }^{6}$ International students are not counted within these numbers and are categorized separately. learning, research and scholarship; equality cannot be measured simply in terms of access and enrollment. As Unterhalter (2006) stated,

The feminist novelist Angela Carter...suggested a generative metaphor. Once women were invited to the dinner party of higher education, she asked, could they complain about the food?...I want to take her question further. How do they ask questions about who cooked and washed up and under what work conditions? Can they consider how access to this dinner party does and does not support those who may never eat a meal on this lavish scale? And if they pose these questions are they really guests or only impostors barely tolerated, forever outsiders?

Carter's questions and considerations should be extended to all underrepresented and "targeted" groups at the University and educational institutions as a whole. They call for the need to evaluate "diversity" programs beyond the quantitative measures of number of individuals. Currently, the campus has experienced a climate of slow progress and avoidances of the recommendations of the Holley Report. Multicultural organizations and initiatives have come under attack with many losing funding. Across the campus and within University publications there has been a vocal attack or 'debate' about the university's affirmative action policies. These discussions make students of color feel like unwelcomed "guests". This is so because the attacks on affirmative action policies that would help some students of color achieve admission to the university implicitly, perhaps unintentionally, raise questions about any and all students of students of color on the campus. Many students of color have also commented (in personal communications, university publications and student-directed documentaries) about their lack of inclusiveness and reported on the daily micro- and macro-aggressions they face (see the "I, too, am UWMadison" Tumblr).

A number of students experience exclusion and othering based on multiple identity markers (race, class, gender, sexuality, ability, etc.). And for a number of students this exclusion is felt from the moment they apply to the university. This is especially true for biracial or multiracial students, who like all students are asked to categorize themselves according to race and ethnicity. They are asked to select one of the options given and if they do not fit into one of the specified categories or if they fit into multiple categories they must mark "other". These students are solidified as "Other" upon their enrollment.

Once on campus students of color are met by a predominantly White student and faculty body as well as subtle racism from their peers and others around them. The experiences of students of color, who targeted through the multicultural diversity initiatives, are 
very different from White students, who may be targeted as "disadvantaged" for coming from low-income families or as first generation college students (Sisneros, 2011; Williams, 2013). While the representation of multiple underrepresented and historically marginalized groups in institutions of higher education is important, White students' experiences are different because of how they are generally able to blend in in their classes in ways students of color cannot at a predominantly White institution, such as UW-Madison (Sisneros, 2011; Williams, 2013). Additionally, the competitive disposition of the university that generally fosters individualism, more so than collective learning on the part of students, is antithetical to some students' whose world views and beliefs is in collective support and responsibility to their community.

In response, students create spaces of mutual support and gather with other like-mind students in order to address the problems and issues they face. Some of these more formal spaces, however, have been targeted and lost funding. For example, in 2013, the Multicultural Student Center (MSC), which arose out of the Holley Report and the Madison Plan, has received minimal funding from the student government's finance committee and in previous years (2011 for example) the MSC was denied any student government funding (Hintz, 2011; Larkins, 2013). Stronger support for students and a recognition of their historical struggles and value is needed to begin to facilitate greater inclusion of an increasingly more diverse student body.

In addition, and of major significance, the ethnic studies programs and the Afro American Studies Department, which emerged out of students' struggles, have come under attack. Many have been losing funding annually and there is currently a move to consolidate the programs into one department, thereby unraveling the tireless work and efforts of students and faculty of the university. The move to consolidate, however, is being met with organized resistances.

\section{Conclusion}

In this moment of conservative pushback against racial and ethnic progress in the US, UW-Madison must not relax efforts to promote greater inclusion of students of color, their voices and knowledge on this campus. The arc of justice that includes a climate of "campus diversity" has struggled forward because of students' persistence. Change in the U.S., is often born out of protest and struggle. Such was the case at UW-Madison. Greater access and representation of multiple groups on campus, the establishment of ethnic studies programs and departments and the Holley Report that paved the way, all came about because of students' persistence. When students consider their places at the educational "table", what if those seats were no longer seen as "disadvantaged", but instead hard fought for positions?
In sum, this historical case study shows how notions of diversity and "disadvantage" have operated differently in different contexts in the State of Wisconsin and at its flagship university. Many European immigrants in the 1800 s would have been seen as "disadvantaged", but this condition was not continually held as a barrier to their personhood and belonging because of their race. However, marginalized students at UW were viewed, and continue to be viewed, as deficient and "disadvantaged" (through socially constructed notions of race, class, gender, sexuality, etc.). Because of this viewing of marginalized students, they have had to continually struggle for cultural recognition and social inclusion. This paper represents an exploration of the histories of students organizing and movements at UW-Madison to raise questions such as: how does the framing of people and the discourses around diversity initiatives (words such as disadvantage) affect what responses are possible? And how can we change universities' institutional framings, imaginaries, climate and culture in order to promote full inclusion of all those who make up this nation? Such "thick" inclusion calls for a deep engagement with histories of students' continued struggles and continued demands. However, due to constraints on space this represents only a partial exploration; there are gaps in years and a full depiction of the multiple and interconnected on-going struggles of students for full inclusion across the campus.

We hope that this paper will encourage others to explore and delve into the gaps and silences to open spaces for deeper discussions of campus histories, current policies and future directions. We do not seek to offer fixed "solutions" or a step-by-step guide for universities, instead we encourage administrators, faculty and students to explore the histories of struggle on their campus and listen to the voices of "othered" students whose voices are often silenced or de-centered during debates about the policies and futures of their university. Understanding the struggles that led to many current policies and initiatives will hopefully make it more challenging to their outcomes to be reversed or undermined through top-down policies without the full input of students.

\section{Acknowledgements}

We would first of all like to thank all who participated in the interviews as well the 2013-2014 residents of the UW-Madison Multicultural Learning Community for their critical feedback and comments to previous drafts of this article.

\section{Conflict of Interests}

The authors declare no conflict of interests. 


\section{References}

Al-Jazeera America (2014). Black students at University of Michigan demand action on campus diversity. The Stream Official Blog. Retrieved from http://america. aljazeera.com/watch/shows/the-stream/the-streamofficialblog/2014/1/21/black-students-atuniversityof michigandemandactiononcampusdiversi.html

American Association for Affirmative Action. (2013). Affirmative Action Defined. Retrieved from http://ww w.affirmativeaction.org/about-affirmative-action

Anyon, J. (2005). Radical Possibilities: Public Policy, Urban Education, and a New Social Movement. New York: Routledge.

Biondi, M. (2012). The Black Revolution on Campus. Berkeley and Los Angeles: University of California Press.

Bonilla-Silva, E. (2013). Racism without Racists: ColorBlind Racism and the Persistence of Racial Inequality in America. Lanham, Maryland: Rowman \& Littlefield Publishers.

Brown, D. A. (1971). Bury My Heart at Wounded Knee: An Indian History of the American West. New York: Holt, Rinehart \& Winston.

Cammarota, J., \& Romero, A. (Eds.) (2014). Raza Studies: The Public Option for Educational Revolution. Tucson: The University of Arizona Press.

Change.org. (2014). Petitioning Dean Rachel Moran, UCLA School of Law: Substantively Respond to BLSA's Suggestions for a Less Hostile Campus Climate. Change.org. Retrieved from https://www.change.org /petitions/dean-rachel-moran-ucla-school-of-lawsubstantively-respond-to-blsa-s-suggestions-for-aless-hostile-campus-climate-2

Crow, L. D. (1966). Educating the Culturally Disadvantaged Child: Principals and Programs. Philadelphia: David McKay Company.

Deutsch, M. (1967). The disadvantaged child. New York: Basic Books.

Diversity Forum. (2011). Retrieved from http://www. apa.wisc.edu/diversity.html

Education Optimists. (2011). Retrieved from http://the eduoptimists.com/tag/center-for-equal-opportunity

Fairclough, N. (1989). Language and power. Edinburgh Gate: Addison Wesley Language Limited.

Final Report on Plan 2008. (2009). Reflections on the Past, Prospects for the Future. Working Draft, February 23, 2009.

Fisher v. University of Texas at Austin. (2013). Supreme Court of the United States, No. 11-345.

Gilbert, C. K. (2011). Their times \& legacy: African American activism in the black campus movement at university of Wisconsin-Madison and its enduring impulse. Retrieved from http://udini.proquest.com/ view/their-time-and-their-legacy-african-pqid:2538 295001

Greendeer, M. M. (2002). Speech on Wisconsin Trea- ties, Ho-Chunk Land Losses Exclusive to Monroe County, Wisconsin. Retrieved from https://nelson. wisc.edu/ltc/docs/mg0203spe.pdf

Haines, D. (Ed.) (1989). Refugees as Immigrants: Cambodians, Laotians, and Vietnamese in America. Totowa, New Jersey: Rowman \& Littlefield.

Hale, F. (1984). The Swiss in Wisconsin, Wisconsin Historical Society. Retrieved from http://mki.wisc.edu/ Ethnic/ethn-his.html

Hartshorne, D. (Interviewer), \& Doyle, R. (1982). Oral History Interview: Ruth Doyle. UW-Madison Oral History Program Website. Retrieved from http:// minds.wisconsin.edu/handle/1793/61944

Hintz, M. (2011). MCSC loses suit against student gov't. Badger Herald. Retrieved from http://badgerherald. com/news/2011/12/01/mcsc-loses-suit-agai/\#.UvQ S8fZL4a1

Holley, C., Arenas, A., Bowles, A., Cantu K., Casanova S., Fausett, R. S., Garcia, V., Ginsberg, P., Hampton, A., Ho, W., Horn, A., Jew, V., Lerner, G., MacNabb, A., March, R., McGinnis, R., Norsetter, R., Puig-Lugo, H., Ramirez, R., Renville, J., Scott, D., Stitt, L., Wenner, M., Werner C., \& Wilson, F. (1987). Steering Committee on Minority Affairs, University of Wisconsin-Madison: Final Report. Madison, WI: University of Wisconsin-Madison.

Holmes, F. (1990). Old World Wisconsin (2 ${ }^{\text {nd }}$. ed.). Madison: Wisconsin Historical Society. Retrieved from http://mki.wisc.edu/Ethnic/ethn-his.html

International Alliance of Leading Education Institutes (IALEI). (2012). Educational Disadvantage. Retrieved from http://www.intlalliance.org/ialeithemes

Indiana Daily Student. (2014). Student petitions to stop proposed 'Ethnic Studies' merger. IDS News. Retrieved from http://www.idsnews.com/article/ 2014/04/student-petitions-to-stop-proposedethnic-studies-merger?id=97781

Larkins, C. (2013). Student government hears MCSC internal appeal, approves budget for Campus Women's Center. Badger Herald. Retrieved from http:// badgerherald.com/news/2013/10/22/studentgovernment-hears-mcsc-internal-appeal-approvesbudget-campus-womens-center/\#.UvQS7fZL4a1

Long, D., \& Veroff, D. (2007). A brief history of immigration in Wisconsin. Madison: University of Wisconsin Extension \& Applied Laboratory. Retrieved from http://www.apl.wisc.edu/publications/APL_ Rural_Immigration_Summit.pdf

Lucha y Resiste. (2013). University of Florida SDS demands tuition equity. Fight Back News. Retrieved from http://www.fightbacknews.org/es/node/3769

Martinez, S. L., \& Rury, J. L. (2012). From "Culturally Deprived" to "At Risk": The Politics of Popular Expression and Educational Inequality in the United States, 1960-1985. Teachers College Record, 114, 060305.

Mechanic, D., \& Tanner, J. (2007). Vulnerable people, 
groups, and populations: Societal view. Health Affairs, 26(5), 1220-1230. Retrieved from http:// content.healthaffairs.org/content/26/5/1220.full

Meyer, R. W. (1993). History of the Santee Sioux; United States Indian Policy on Trial. Lincoln: University of Nebraska.

McAdam, D., Tarrow, S., \& Tilly, C. (2001). Dynamics of Contention. New York: Cambridge University Press.

National Assessment of Educational Progress (NAEP). (2013). Wisconsin has the largest achievement gap between blacks and Whites. NCES. Retrieved from nces.ed.gov/nationsreportcard

Nelson, L. (2012). Another Cut for Grad Student Aid. Inside Higher Ed. Retrieved from http://www.inside highered.com

Okihiro, G. Y. (2010). The Future of Ethnic Studies: The field is under assault from without and within. The Chronical of Higher Education. Retrieved from http://chronicle.com/article/The-Future-of-EthnicStudies/66092

Ornstein, A. C. (1970). Educating the Disadvantaged. New York: AMSPress.

Pereira, S. R. (Ed.) (2014). Regeneración. Chican@ and Latin@Studies Program at University of WisconsinMadison Newsletter. Madison: University of Wisconsin-Madison.

Plan 2008. (1998). Plan 2008: Educational Quality through Racial and Ethnic Diversity. Madison: UW System Board of Regents. http://www.uwsa.edu/ edi/plan/diversit.pdf

Portes, P. (1996). Ethnicity and Culture in Educational Psychology. In D. Berliner \& R. Calfee (Eds.), Handbook of Educational Psychology (pp. 331-357). New York: Macmillan Library Reference.

Race to Equity. (2013). Wisconsin Council on Children and Families. Race to Equity. Retrieved from http://racetoequity.net/dev/wpcontent/uploads/WCCF-R2E-Report.pdf

Riessman, F. (1962). The culturally deprived child. New York: Harper and Row.

Robinson, A. L., Foster, C. C., \& Ogilvie, D. H. (Eds) (1969). Black Studies in the University: A Symposium. New Have: Yale University Press.

Ryan, R. (2014) Dear White People. Madison Magazine, p. 26.

Stanford Historical Society (2011). Sandstone and Tile, 35(1). Retrieved from http://historicalsociety. stanford.edu/pdfST/ST35no1.pdf

Schereck, W. J. (1955). The Peoples of WisconsinMadison. Retrieved from www.naha.stolaf.edu/ pubs/nas/volume19/vol19_9.htm

Schuette v. Coalition to Defend Affirmative Action (2013). Supreme Court of the United States, 133 S.Ct. 1633.

Selman, P. (2011). Center for Equal Opportunity alleges UW discriminates against White applicants, students respond with protest. Ismus: The Daily Page.
Retrieved from http://www.thedailypage.com/ daily/article.php?article $=34650$

Siegel, R. (2004). Lyndon Johnson's War on Poverty. Historians. Retrieved from http://www.historians. org/pubs/free/WhyStudyHistory.htm

Sisneros, K. (2011). The Forgotten Voices Behind Designated Diversity Initiatives: Perspectives from Students of Color Living in a Multicultural Residential Community (PhD Dissertation). Retrieved from http://scholarwoks.umass.edu/open-accessdissertations $/ 413$

Slesinger, D. P., \& Parra, P. A. (1988). Blacks in Wisconsin: A 1980 Chartbook. Madison, WI: Applied Population Laboratory, University of Wisconsin-Madison

Smith, J. (2012). This day in resistance history: 1968 Columbia student uprising. Griid. Retrieved from: http://griid.org/2012/04/23/this-day-in-resistancehistory-1968-columbia-student-uprising

Stokes, S. (2013). The Black Bruins [Spoken Word]. YouTube. Retrieved from https://www.youtube. $\mathrm{com} /$ watch?v=BEO3H5BOIFk

Torres, A. (2014). Forget Color-Blindness. National Review Online. Retrieved from http://www.national review.com/article/369871/forget-color-blindnessalec-torres

Ture, K., \& Hamilton, C. V. (1992). Black power. New York: Vintage.

Tyack, D., \& Cuban, C. (1995). Tinkering toward utopia: A century of public school reform. Cambridge, MA: Harvard University Press.

Unterhalter, E. (2006). New times and new vocabularies: Theorising and evaluating gender equality in Commonwealth higher education. Women's Studies International Forum, 29(2006), 620-628.

University of Wisconsin-Madison News. (2011). UWMadison responds to attacks on diversity efforts. 13 September 2011. Retrieved from http://www. news.wisc.edu/19754

University Housing. (n.d.). Welcome to Dejope Hall. University of Wisconsin-Madison Housing. Retrieved from http://www.housing.wisc.edu/dejope

Valencia, R. (1997). Conceptualizing the Notion of Deficit Thinking. In R. Valencia (Ed.), The Evolution of Deficit Thinking: Educational Thought and Practice. Abingdon, Oxon: RoutledgeFalmer.

Wells, S. (2014). The troubles at Stanford: Student uprisings in the 1960s and 70s. Sandstone \& Tile, 35(1). Retrieved from http://historicalsociety. stanford.edu/pdfST/ST35no1.pdf

Williams, D. (2013). Strategic Diversity Leadership: Activating Change and Transformation in Higher Education. Sterling, VAL Stylus Publishing.

Williams, P. (2010). 1970 Kent State and Jackson State shootings. Yahoo! Voices. Retrieved from voices.yahoo.com/1970-kent-state-shootings-5963688 html

Wisconsin Historical Society "Turning Points". (n.d). Re- 
trieved from http://www.wisconsinhistory.org/ turningpoints/tp-049/?action=more_essay

Wisconsin Historical Society. (2006). Hispanic Heritage Month. Wisconsin Historical Society. Retrieved from http://www.wisconsinhistory.org/highlights/archiv es/2006/09/hispanic_herita.asp
Wisconsin Historical Society. (n.d). Ethnic Groups in Wisconsin: Historical background. Wisconsin Historical Society. Retrieved from http://mki.wisc.edu/ Ethnic/ethn-his.html

Wisconsin Idea. (n.d.). Retrieved from http://wisconsin idea.wisc.edu

\section{About the Authors}

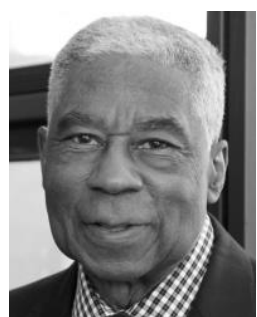

\section{Dr. Carl Grant}

Carl A. Grant is Hoefs-Bascom Professor at the University of Wisconsin-Madison. He has authored or edited thirty-seven books and has written more than one hundred journal publications. He was President of the National Association for Multicultural Education (1993-1999), Editor of Review of Education Research (1996-1999), member of AERA Fellows and Vice-President of AERA Curriculum Studies Division. Dr. Grant received the University Wisconsin School of Education Distinguished Achievement Award, AERA's Social Justice Award, AERA's Mentor Award and is a member of the Kappa Delta Pi Laureate Society.

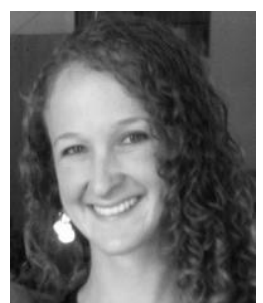

\section{Alexandra Allweiss}

Alexandra Allweiss is a PhD student in Curriculum and Instruction and Educational Policy Studies at the University of Wisconsin-Madison. Her research interests include multicultural and social justice education, critical theories, intersectionality in educational experiences, and youth and community activism and organizing in education. Before coming to UW-Madison, she worked as a middle school and high school teacher in Guatemala. 